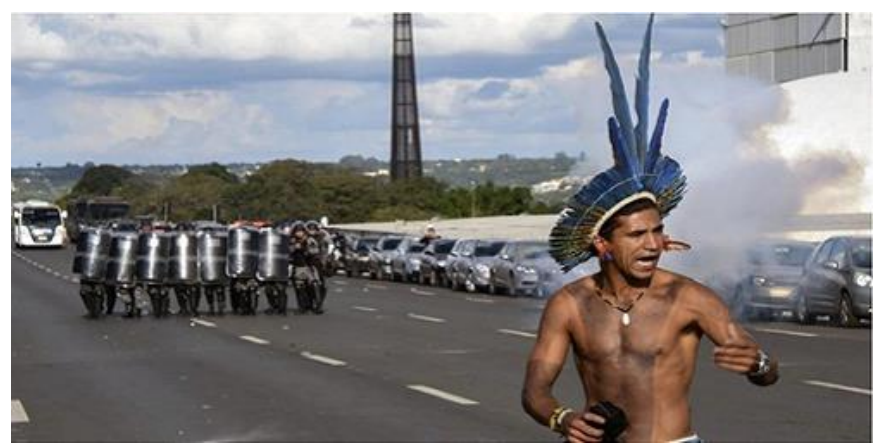

\title{
Perspectivas da análise do (in)visível: a arquitetura discursiva do não verbal
}

Perspectives in the analysis of the (in)visible: the discursive architecture of nonverbal

Tania Conceição Clemente de Souza ${ }^{1}$

\section{Resumo:}

Há algum tempo, a análise do não verbal vem despertando nosso interesse, no sentido de se pensar alguns aspectos que são instituídos na e pela discursividade: a materialidade discursiva do não verbal e sua arquitetura e como se textualiza o político em termos não verbais. Estes aspectos perduram no trabalho em pauta, quando colocamos em discussão três conceitos punctum (BARTHES, 1980), intericonicidade (COURTINE, 2013) e policromia (Souza, $1997 \mathrm{e}$ 2001) -, sublinhando o alcance de cada um desses conceitos na análise da textualidade do não verbal. E investindo na interface destes três conceitos. Calcados em pressupostos da Análise de Discurso, investimos na análise de quatro fotos veiculadas na mídia on line, sobre a cobertura do embate da polícia com índios em abril de 2017.

Palavras-chave: Punctum. Intericonicidade. Policromia. Arquitetura do não verbal.

\begin{abstract}
:
There is a time, the analysis of nonverbal arouses our interest, in the sense of thinking about some aspects that are instituted by discursiveness: the discursive materiality of the nonverbal and its architecture, and how the political gestures are textualized in a nonverbal language. These aspects remain in the work in question, when we put in discussion three concepts punctum (Barthes, 1986), intericonicity (COURTINE, 2013) and polychromy (Souza, 1997 and 2001) -, highlighting the scope of each of these concepts in the analysis of textuality of the nonverbal. We also invest in the interface of these three concepts. Under the assumptions of Discourse Analysis, we proceed the analysis of four photos published in the online media about the coverage of the police clash with indigenous in April 2017.
\end{abstract}

Keywords: Punctum. Intericonicity. Polichromy. Image analysis. Architecture of nonverbal.

\footnotetext{
${ }^{1}$ Doutora em Linguística pela Unicamp. Professora Associada do Departamento de Antropologia do Museu Nacional/UFRJ. Professora da Pós-graduação em Linguística da Faculdade de Letras/UFRJ. ORCID ID: https://orcid.org/0000-0001-6782-7465. E-mail: taniacclemente@ gmail.com
} 


\section{Introdução}

o real não está na saída nem na chegada, ele se dispõe para a gente é no meio da travessia. Guimarães Rosa

Por que pensar a imagem na ordem do discurso? Essa é uma questão com a qual há algum tempo venho esbarrando, o que me tem levado a um investimento teórico, na busca, principalmente, de refletir sobre como se textualiza o político em termos não verbais. (Cf. Souza, 1996, 1997, 1999, 2000, 2001, 2011, 2012, 2013, 2013 a , 2014, 2017). Nesse percurso, outras questões se atravessam: como se institui a materialidade discursiva do não verbal? como as paráfrases visuais trabalham o fio da memória? como pensar a arquitetura do não verbal? A resposta a estas questões não são imediatas, por isso mesmo (re)tomo algumas das considerações que venho formulando a respeito, somando a outras reflexões - afinal, o sujeito e os sentidos são históricos! - e me vejo às voltas com outra "provocação": existe um real do visível?

Eis aí, como estão perfilados os objetivos principais deste trabalho. Pretendo recuperar algumas das discussões e propostas sobre a análise do não verbal e investir um pouco mais na definição da arquitetura discursiva do não verbal. Enfim, vamos explorar diferentes perspectivas que podem sustentar a análise do não verbal - como as trazidas por Barthes e Courtine. Estamos voltados também a explicitar como se constitui, em nossa sociedade, o mito da visibilidade. Como trajeto teórico emprestamos da Análise de Discurso princípios teóricos basilares e recorto como objeto de análise fotos veiculadas na mídia on line de um confronto entre índios e policiais, em Brasília, em abril de 2017.

\section{Três perspectivas de análise da imagem}

Antes de entrarmos no tema central deste trabalho, trago a foco princípios voltados ao trato da imagem propostos por Barthes, por Courtine e em vários de nossos trabalhos. Colocamos em discussão três conceitos - punctum (BARTHES, 1986 [1980]), intericonicidade (COURTINE, 2013 [2011]) e policromia (SOUZA, 1997 e 2001) -, sublinhando o alcance de cada um desses conceitos na análise da textualidade do não verbal. E investindo na interface destes três conceitos. 


\section{(I) Momentos de fuga da Semiologia: significação, significância e a câmara clara}

A Roland Barthes é atribuído o investimento na Semiologia, como método de análise da imagem. Dentro de uma vertente estruturalista, o autor transpõe a noção de signo saussereano para o enfoque da imagem. Entretanto, a meu ver, o próprio autor propõe em alguns trabalhos a discussão do estudo semiótico numa perspectiva estreita, introduzindo, por exemplo, numa posição diferente da de um estruturalista, a noção de sujeito e formulando outras concepções que também escapam ao estruturalismo. Recupero, aqui, dois trabalhos: O óbvio e o obtuso (BARTHES, 1990 [1982]²), que reúne diversos escritos do autor numa última publicação, após sua morte e A Câmara Clara (1986, [1980]), seu último livro.

Em $O$ óbvio e o obtuso, a partir da análise de fotogramas ${ }^{3}$ de Einsenstein, são propostos três níveis de sentido. Um nível informativo decorrente de todo o conhecimento "trazido pelo cenário, vestuário, personagens, as relações entre eles, sua inserção em uma trama que conheço (ainda que de maneira vaga)". Este é o nível de comunicação, onde se procede à semiótica da mensagem ${ }^{4}$. Um nível simbólico: ouro derramado sobre a cabeça do Imperador. Significa o ritual imperial do batismo, quando se tem um simbolismo referencial. Há, em seguida a este: o simbolismo diegético, com o tema do ouro, da riqueza; um simbolismo eisensteiniano, decorrente de todos os deslocamentos próprios ao cineasta e, por fim, um simbolismo histórico. Este segundo nível, em seu conjunto, se define como o nível da significação. E, por fim, um nível, que por ser "evidente, errático e teimoso terceiro sentido", o autor não consegue dar-lhe um nome.

A dificuldade em nomear o terceiro nível é porque a descrição extrapola a relação significante/significado. Nos deparamos, então, com o nível da significância: em jogo apenas o significante. Enquanto o nível da significação abrange os sentidos simbólicos, referenciais, temos que aqui o sentido é óbvio, portanto, diferente do nível da significância, o nível do sentido obtuso. Mas o que seria este terceiro sentido, obtuso?

O obtuso, é o “demais". Sentido vedado, que escapa à intencionalidade do autor. O sentido obtuso não está na língua, sem ele permanecem a comunicação e a

\footnotetext{
${ }^{2}$ Roand Barthes falece em 1980, em 1982 são reunidos vários artigos em L'OBVIE ET L'OBTUS ESSAIS CRITIQUES III, Editions du Seuil.

${ }^{3}$ Os fotogramas fazem parte do filme "Ivan o Terrível, extraídos dos Cahiers du Cinéma números 217 e 218. (nota do autor)

${ }^{4}$ Barthes, claramente, declara que não mais tratará dessa semiótica, nem deste nível. (idem, 1986: 45)
} 
significação. Nem está em todo lugar. É errático. É um significante sem significado. Logo: não está situado estruturalmente. Perturba, esteriliza a metalinguagem. Não se esvazia nunca. Enfim o terceiro sentido é a passagem da linguagem à significância. Mas só existiria no cinema, sendo o próprio ato fundador do fílmico ${ }^{5}$.

Se, como vimos acima, o sentido óbvio está para a intencionalidade do autor, o sentido obtuso, o "demais" (grifo do autor) foge a esta intencionalidade: o sentido nos fotogramas "forma aí um dialogismo tão tênue, que não se pode ter certeza da intencionalidade" (idem: 50). O sentido obtuso está para quem lê sem pressupor qualquer intencionalidade do autor, está, assim, para os efeitos de sentido traduzidos pelo espectador/leitor.

Em Câmara Clara o distanciamento de Barthes da Semiologia é bem evidente, quando apartado do seu lugar de semiólogo, decide compreender a fotografia com um outro olhar:

\begin{abstract}
"Meu interesse pela Fotografia adquiriu uma postura mais cultural. Decretei que gostava mais da Foto contra o cinema, do qual, todavia, eu não chegava a separá-la. [...] em relação à Fotografia, eu era tomado de um desejo "ontológico": eu queria saber a qualquer preço o que ela era "em si", por que traço essencial ela se distinguia da comunidade das imagens." (BARTHES, 1986: 11-12).
\end{abstract}

O título do livro - Câmara Clara - parece contribuir a esse afastamento, por oposição à câmara escura (a máquina fotográfica); câmara clara é um instrumento de prismas de reflexão, com o qual se vê ao mesmo tempo o objeto e a sua imagem projetada sobre uma folha de papel. É com uma outra lente, que Barthes vai discorrer sobre a fotografia e desse outro olhar, destaco o conceito de punctum, já utilizado por mim em vários trabalhos.

Sobre a noção de punctum "traço essencial da foto", podemos estabelecer uma relação com a noção de studium, do mesmo autor. Embora Barthes não tenha a preocupação de definir precisamente esses dois conceitos, ao contrário, ele parece preferir divagar em torno dos efeitos de sentidos que ele experimenta diante de várias fotografias, jogando ora com o studium, ora com o punctum, pode-se resumir o alcance significativo dessas duas noções assim: o studium está para a intencionalidade do fotógrafo; atende ao desejo de capturar o instante; o punctum é aquilo que, apesar de flagrado, foge a essa intencionalidade; o punctum é tudo o que se faz suscetível ao olhar do espectador. O punctum catalisa uma série de sentidos e dá margem a

\footnotetext{
${ }^{5} \mathrm{O}$ ato fímico, segundo o autor, se diferencia do filme, pois o fílmico só apareceria no fotograma e não na imagem em movimento. (idem: 58)
} 
inúmeras interpretações ( $C f$. SOUZA, 2011). Do ponto de vista discursivo, defino o punctum como um traço de textualidade inerente ao caráter de incompletude da fotografia. O punctum se define como algo casual, fugaz, por isso mesmo, do nosso ponto de vista, tem relação com a memória, com o interdiscurso, porque abre a interpretação. A partir do punctum, há toda uma instituição de dizeres, que nos remete à atualização da memória face ao sentido instituído pelo esquecimento. Ainda do ponto de vista discursivo, o punctum pode significar a falta, a ausência daquilo que o olhar não vê, mas que está lá significando." (SOUZA, idem).

Sobre o conceito de punctum, é válido frisar que ele é inerente à fotografia, considerando a sua presença fugaz e ocasional. Funciona como um extra-campo, como diz Barthes, quando o espectador institui o punctum, recortando um determinado detalhe na foto e, a partir daí, constrói toda uma narrativa paralela, alheia ao que a foto mostra, por isso faz trabalhar a memória, como o autor faz em vários exemplos no livro ${ }^{6}$. Indagado sobre a proposta de Roland Barthes, ao definir o sentido obtuso e o punctum, Courtine (aqui citado) adverte que que "não é da linguística saussureana que estas ideias procedem, e, sim, muito mais da psicanálise: o obtuso e o punctum não são da ordem do signo, mas daquilo que ressoa nos signos, à maneira do lapso vindo a romper as evidências da cadeia significante" (COURTINE, 2013: 42). $\mathrm{Na}$ leitura que fazemos dos dois conceitos, nos parece clara a postura de Roland Barthes de se abster da linguística, tanto assim que ele parte da sua posição de espectador para pensar a significância - e não a significação - de fotogramas, de detalhes nas fotos. Como ele mesmo diz, são conceitos que esterilizam a metalinguagem, o sistema, acrescento. E o fato de estes conceitos terem relação com a psicanálise - "nada de signos, mas de indícios ... de um sentido imprevisto" (ainda Courtine) - é que nos permite pensá-los na ordem do discurso, desde há muito tempo ${ }^{7}$.

\section{(II) Intericonicidade: o sempre-já da imagem}

Em Decifrar o corpo - pensar com Foucault, Courtine (2013 [2011]), num texto com formato de entrevista, intervém no estudo da imagem, sublinhando, principalmente, que o que quis fazer, ao propor o conceito de intericonicidade, foi, de um lado, "sublinhar o caráter discursivo da iconicidade" - discurso tomado de Foucault, no sentido de fragmento, ou centelha de imagem - , por outro lado, remeter

\footnotetext{
${ }^{6}$ Em Souza (2011 e 2013, dentre outros), exploro a noção de punctum em vários exemplos.

${ }^{7}$ Trabalhamos com a noção de punctum desde a nossa tese de doutorado, defendida em 1994.
} 
o conceito de intericonicidade à noção de memória discursiva: "a ideia de memória discursiva implica que não existem discursos que não sejam interpretáveis sem referência a uma tal memória [...]. Eu diria a mesma coisa da imagem: existe um "sempre-já" da imagem." (idem: 40-41).

A reflexão sobre a imagem implica em certos deslocamentos dos procedimentos de análise na base dos recorte lexicais, ou sintáticos e outros, porque discurso se define aí como objeto linguístico. O autor retoma, assim, Foucault (1969) em Arqueologia do saber para se desvincular de discurso numa concepção linguística: "a imagem não obedece em nada a um modelo de língua." (idem) Daí também, Courtine não transpor o conceito de interdiscurso como procedimento de análise da imagem.

A noção de intericonicidade supõe relacionar conexões de imagens: "imagens exteriores ao sujeito, como quando uma imagem pode ser inscrita numa série de imagens, uma arqueologia, à maneira do enunciado numa rede de formulações". (idem: 44) Ao buscar um exemplo de todo esse processo, Courtine retoma o episódio do World Trade Center. As imagens do ataque ao WTC se reproduzem numa difusão quase infinita. São seis imagens repartidas em quase trinta. Por que, precisamente, estas seis imagens e não outras? "Porque elas mesmas repetem alguma coisa na cultura visual e na memória coletiva americanas." A imagem da nuvem de fumaça sobre o WTC indicia uma outra nuvem: "a que elevava abaixo do Pearl Harbour após o bombardeamento aéreo japonês”. (p. 45) Como efeito de sentido, a imagem diz que ontem e hoje, os Estados Unidos estão sempre em guerra. A imagem da bandeira sobre os escombros do WTC é o indício da outra, porém mesma, bandeira içada sobre a ilha do Hiroxima. O que significa que esta guerra também será vencida. Este exemplo resume, assim, como deve ser a análise da imagem: referenciar os indícios.

\section{(III) Policromia, paráfrases e arquitetura do não verbal}

A definição do conceito de policromia teve como motivação as reflexões de Orlandi (1992 e 1995) sobre o não-verbal, aliada ao fato de estar lecionando num curso de Comunicaçao Social, quando os alunos indagam se seria possível se analisar as imagens numa perspectiva dicursiva. Ainda em 1996, elaborei uma apostila de aula, quando já defino o conceito de policromia. Em 1997, no 2o. Coloquio Latinoamericano 
de Analistas del Discurso, torno pública a apresentação do conceito na comunicação Discurso e imagem: perspectivas de análise do não-verbal ${ }^{8}$.

O termo "policromia" tem na sua base o radical -cromo-, utilizado com o sentido aproximado de cromolitografia, arte de estampar em relevo figuras coloridas. Recobre, portanto, o jogo de imagens, cor, luz e sombra, etc presentes às imagens. Como dispositivo de análise, policromia se define como gesto que permite, ao se interpretar a imagem, projetar outras imagens, cuja materialidade, não é da ordem da visibilidade, mas da ordem do simbólico e do ideológico. Da ordem do discurso. A policromia revela a imagem em sua natureza heterogênea, ou melhor, como conjunto de heterogeneidades que, ao possuírem uma co-relação entre si, emprestam à imagem a sua identidade. Essa co-relação se faz através de operadores discursivos não-verbais: a cor, o detalhe, o ângulo da câmara, um elemento da paisagem, luz e sombra, etc, os quais não só trabalham a textualidade da imagem, como instauram a produção de outros textos, todos não-verbais.

Ao se definir policromia como rede de elementos visuais, implícitos ou silenciados, verifica-se que são esses os elementos que possibilitarão as diferentes interpretações do texto não-verbal. Com isso, se diz que as imagens não são visíveis, tornam-se visíveis a partir da possibilidade de cada um projetar as imagens possíveis, que necessariamente, não compõem a estrutura visual do texto não verbal em si, mas que compõem a rede de imagens mostradas, indiciadas, implícitas, metaforizadas ou silenciadas.

O trabalho com o conceito de policromia nos faz chegar a como se dá a textualização do político no âmbito do não verbal. Quando se afirma que uma imagem não é visível, mas torna-se visível através dos gestos de interpretação, se pressupõe o alcance político-ideológico inscrito no uso que se faz das imagens. Uma imagem apaga outra, a imagem da bandeira dos Estados Unidos, citada no exemplo acima, apaga a imagem da derrota. Não é por acaso que a bandeira americana se sobrepõe aos destroços, num gesto de denegar a tragédia e em nome da propagação de uma soberania ufanista. Explicitar a textualização do político é "apontar como o político pode se textualizar em imagens que, aliadas a outros recursos, têm a um só tempo a sua

8 Texto publicado na revista CIBERLEGENDA, v.1, p.15 - 32, 1998. Uma versão ampliada em termos de reflexão e ilustrada com análise da mídia impressa, do cinema e da mídia televisiva veio a ser publicada em Rua, Campinas: 7, Pontes, 2001, sob o título A análise do não verbal e os usos da imagem nos meios de comunicação. 
visibilidade apagada no intuito de dar corpo a uma memória da ordem do discurso, do ideológico. Explicitar como se dá o silenciamento das imagens é pôr à mostra o jogo de relações de forças que subsidiam o imaginário social, base dos discursos sobre. $\mathrm{O}$ mito da visibilidade se forja na relação do simbólico com o imaginário, sustentando o fato de que as "imagens falam por si" e projetando como naturais sentidos que, na verdade, são historicamente construídos por esse jogo de relações de forças". (SOUZA 2011, e outros).

O enfoque discursivo das imagens não é, para nós, apenas uma questão de descrever a sua organização textual buscando entender aí traços de estética, ou ir em busca de traços que digam de uma lógica, ou de uma possível coesão textual. A imagem tem uma organizacão complexa, e como diz Pêcheux (1999) "é muda, sem um trajeto de leitura". Por isso, nossa proposta é trabalhar com o detalhe, ou recorte, sobre o qual recai o olhar. E aí chegar à materialidade discursiva da imagem, e jogar com dois conceitos: paráfrases visuais e arquitetura do não verbal.

Em várias análises de textos não verbais, venho trabalhando com o conceito de paráfrases visuais. Quando se analisa uma imagem pelo viés da policromia, se direciona e se constrói o próprio olhar através dos gestos de interpretação. Gestos que, a um só tempo, recortariam as paráfrases visuais que constituem o corpo da imagem e dariam lugar aos deslizamentos de sentidos, aos efeitos metafóricos, ordenados pela injunção do dizer.

Pensar em paráfrase visuais na arquitetura do não verbal decorre da aproximação que fiz da arquitetura do verbal, proposta por Pêcheux (2011). A expressão "arquitetura" não é usada pelo autor, mas sim por mim. Pêcheux (idem) toma a sintaxe como algoritmo da discursividade e parte da questão de como, textualmente, se constrói o sentido. O sentido resultaria da junção do núcleo autônomo da sintaxe com a produção discursiva. A partir daí enumera diversos tipos de paráfrases cuja base seria o tipo de estrutura sintática em jogo nesse movimento. O autor coloca, então, em discussão, em qual nível de variação lexical pode-se dizer que duas sequências têm o mesmo sentido ou não, argumentando que, somente no âmbito da discursividade, rejeita-se a dicotomia parecido/não parecido e descarta-se a "lógica do sentido". Com o retorno à análise, constata a possível relação entre sintaxe e discursividade: a estrutura sintática da análise chomskiana $^{9}$ da frase aparece, de fato, como a base dos efeitos paradigmáticos,

\footnotetext{
${ }^{9}$ Pêcheux advoga ser a sintaxe o algoritmo do discurso, e elege o modelo proposto por Chomsky (1965: Aspects of the Theory of Syntax), base deste algoritmo.
} 
condicionando a estabilidade da forma lógica subjacente. Mas, face a essa estabilidade paradigmática, a produção discursiva se dá, simultaneamente, numa projeção sintagmaticamente horizontal, como deriva, deixando traços na intradiscursividade da sequência textual. Promove-se, assim, um deslocamento: o rompimento da lógica sintática dá lugar a uma autonomização de um mundo discursivo autorreferido. (idem)

Esse apanhando de reflexões de Pêcheux parece apontar como se organiza a arquitetura da discursividade do verbal. Jogam nessa arquitetura elementos que permitem compreender aquilo que já pode haver de discursivo. Em termos gerais, o que Pêcheux propõe seria o trabalho de interseção de dois eixos: o do intradiscurso, quando a forma-sujeito-autor se propõe a controlar a dispersão do sujeito e o do intrerdiscurso, onde fala uma voz sem nome no trabalho da memória do dizer. Embora o texto de Pêcheux me faz investir na definição de arquitetura do não verbal, tal gesto não me leva a deslocar de forma automática as colocações sobre a constituição da discursividade verbal para a definição da arquitetura do não verbal. A base de todo processo discursivo aí está sustentada pela língua, daí a proposta de a sintaxe ser o algoritmo da discursividade. Quando, porém, se pensa o não verbal - a foto, o cinema, a obra de arte, o corpo, a sonoridade, o traço, etc - conta-se com diferentes fios discursivos. Explicitar como esses fios se articulam é reafirmar, aqui, que a materialidade do não verbal não é única, por isso mesmo, é preciso responder a: como se dá a dispersão do autor do não verbal? como se instituem os dois movimentos do analista - interpretar e compreender o funcionmaneto discursivo, como propõe Orlandi?

A possibilidade de responder a essas questões, em hipótese alguma, nos remete a uma única solução, levando-se em conta a base material de cada forma de discursividade. No cinema, por exemplo, as tomadas de cena, a (des)continuidade, o som, os efeitos de luz e sombra, o contracampo, o extracampo, etc compõem uma arquitetura que é única do cinema (SOUZA, 2013a). Nesse sentido, cada forma de linguagem não verbal pressupõe uma arquitetura específica, que não pode ser pensada como uma estrutura única, nem como uma simples composição com o cruzamento do intradiscurso e do interdiscurso. São muitos os eixos/fios que tecem o não verbal e, consequentemente, são muitos os recursos de ordem teórica que precisam ser acionados na análise de cada uma dessas formas.

É nesse sentido que a arquitetura do não verbal se faz através de paráfrases visuais - ou pelo trabalho da policromia, como definido em Souza (2001) -, quando se opera com a articulação do que é visível ou está implícito, ou do que é apagado, ganha- 
se em visibilidade ao se atestar a falta do que um dia fora visível. Assim, a discursividade se constrói por um movimento de deslizamentos de sentido contínuo. Além disso, as paráfrases visuais tanto podem ser constituídas pelo sujeito no nível da formulação, do intradiscurso, quanto pelo analista, quando da apreensão do sentido no momento da circulação do texto não verbal. Mais adiante, vamos nos ater a analisar algumas fotos e voltaremos a este ponto. Interessante também é retomar aqui o conceito de intericonicidade, proposto por Courtine, que a nosso ver se aproxima do de rede de paráfrases visuais, recuperadas na construção do sentido: o sempre-já da imagem. A que nos remete a nuvem de fumaça pairando sobre a destruição do WTC? Ao cogumelo de fumaça de Hiroxima e Nagasaki. Que sentido pode ser atribuído a tal imagem? Qual o seu alcance indicial? Que os EUA estão sempre em guerra. Esse movimento de sentidos nos remete através do movimento contínuo de paráfrases ao conceito de policromia, onde se textualiza o político.

Partir do conceito de policromia - lugar de textualização do político, no tecido da discursividade não verbal -, aliado ao de intericonicidade, nos permite entender a imagem como dispositivo de intervenção na memória, sem recorrer ao interdiscurso (como também o fez Courtine), mas se postulando um lugar para o pré-construído: daí se poder falar em paráfrases não verbais, que dão corpo à arquitetura do não verbal.

\section{Memória, imagens e acontecimento}

$\mathrm{Na}$ ordem do discurso, o papel da memória é aquele que dá viabilidade ao acontecimento histórico, já que a própria estruturação do discursivo constitui a materialidade da memória social. O que nos leva a considerar aí o estatuto dos implícitos no âmbito da memória. (Cf.: ACHARD, 1999) Do ponto de vista discursivo, o implícito trabalha sobre a base de um imaginário que o representa como memorizado, e cada discurso, ao pressupor esse imaginário, recorre à (re)construção, dando lugar a uma filiação parafrásica, constituindo uma rede de sentidos.

Assim, o passado, mesmo que realmente memorizado, só pode trabalhar como sendo o principal mediador das reformulações que vão permitir enquadrá-lo no discurso concreto face ao qual nos encontramos. Um acontecimento recente, em abril de 2017, registrou o embate da polícia com índios em frente à Esplanada em Brasília, que protestavam sobre a revisão de demarcação de terras. Várias fotos foram veiculadas na mídia, e muitas enviadas aos noticiários estrangeiros. A leitura que faço dessas fotos 
não têm como não me remeter ao passado que ora se atualiza. Começo pela remissão a um velho mito Bakairi.

Desde 1984, trabalho com a língua Bakairi (Caribe). Em 1985, em pesquisa de campo, registrei com a pessoa bakairi mais idosa - a contadora de histórias Waluga - o relato do mito "udódo e pajika", "a onça e o tamanduá". Esse mito fala do confronto entre o índio - udódo 'a onça' - e o não índio - pajika 'o tamanduá'. Em meio à maestria da arte de contar histórias, Waluga descia o tom de voz, se encontrando como narradora, e tecia uma série de comentários. Waluga tinha à época 85 anos (presumidos), era monolíngue como a maioria dos idosos bakairi. Era a minha segunda estada na Aldeia, apenas oito meses depois do meu primeiro contato, por isso ainda não dominava a língua, mas por toda a expressão corporal de Waluga - que ora se levantava e assumia a postura imponente da onça, impostando o tom de voz, ou ora imitava o andar sorrateiro do tamanduá, falando com voz rouca, sempre com um sorriso irônico - apreendia o sentido, mesmo porque eu conhecia outras versões do mesmo mito. Por vezes, Waluga baixava o tom de voz, se dirigindo a mim, como já assinalei em outros trabalhos, procurando me colocar a par da lógica dos fatos que permeavam a narrativa $(C f$. SOUZA, 2008).

São quatro as fotos ${ }^{10}$ aqui selecionadas que me remetem a este velho mito e que as analiso como paráfrases visuais desse velho e eterno confronto: mundo Karaiva $\mathrm{X}$ mundo Bakairi ${ }^{11}$.

O mito começa com o tamanduá convidando a onça para caçar uma anta. Ao tenta flechar a anta, o tamanduá erra o alvo, e Waluga explica (sempre em Bakairi):

"O tamanduá nunca teve flecha. Chíchi, o deus-sol, quando fez o mundo deu flecha para o índio e arma de fogo para o branco.

Este velho mito tem como primeiro registro a data de 1885, quando do contato de Von den Steinen com os Bakairi. Cem anos depois, torno a fazer outro registro do mito e, com surpresa (?), o vejo repetido nos dias de hoje:

\footnotetext{
${ }^{10}$ Não encontramos estas fotos na mídia impressa.

${ }^{11}$ Karaiva é como os bakairi denominam os não índios.
} 


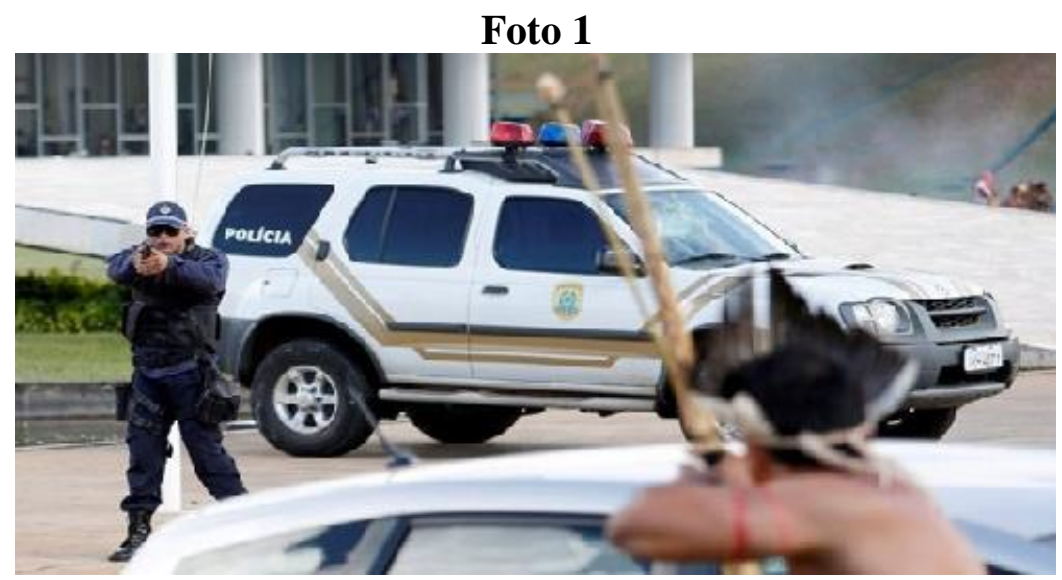

Fonte: http://www.bbc.com/news/world-latin-america-39717329

O embate entre a onça 'o índio' e o tamanduá 'o não índio', mote do mito Bakairi, está aí ressignificado quando da formulação e circulação dessas fotos. Em termos de arquitetura discursivo-visual, temos o domínio do tempo que atualiza o acontecimento, no caso, o confronto entre dois mundos, materializado em paráfrases visuais, instituídas no movimento da análise. O enfrentamento do índio continua sendo com arco e flecha, mesmo diante de armas bem mais potentes.

A segunda foto abaixo me remete à explicação dada por Waluga sobre o tamanduá. A escolha do tamanduá para representar o não-índio não é ao acaso. O tipo de tamanduá, personagem central do mito, é o tamanduá-bandeira (maior mamífero da fauna brasileira), tido como um animal traiçoeiro que, segundo os Bakairi, "abraça por trás". Não há como não me remeter mais uma vez a esse fato, quando da observação da seguinte foto:

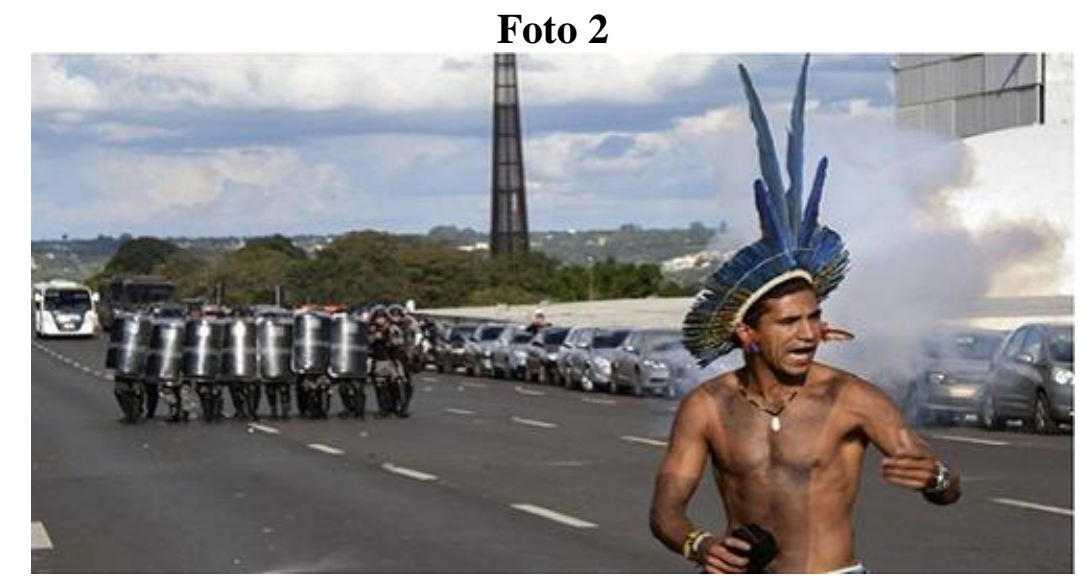

Fonte: http://www.bbc.com/news/world-latin-america-39717329 
O inimigo avança mesmo o índio estando de costas. É assim que o Estado brasileiro trata o indígena. Suas terras serão pilhadas, mas o "mau sujeito" é o índio. Mau sujeito, porque "se contra-identifica com a formação discursiva que lhe é imposta pelo "interdiscurso", como determinação exterior de sua interioridade subjetiva." (PÊCHEUX, 1975). O índio clama por seus direitos já conquistados, como a demarcação das terras, mas acaba rotulado como inoportuno, inconveniente. Trabalhase aí com o imaginário da rejeição, acirrando o preconceito e a homofobia. Mas por que razão essas fotos tiveram uma circulação restrita? Apenas na mídia online?

Sobre memória e mídia, Orlandi (2010) formula o conceito de memória metálica, segundo o qual:

A memória da máquina, da circulação, (...) não se produz pela historicidade, mas por um construto técnico (televisão, computador etc.). Sua particularidade é ser horizontal (...), não havendo assim estratificação em seu processo, mas distribuição em série, na forma de adição, acúmulo: o que foi dito aqui e ali e mais além vai-se juntando como se formasse uma rede de filiação e não apenas uma soma, como realmente é, em sua estrutura e funcionamento. Este é um efeito - uma simulação produzido pela memória metálica, memória técnica. Quantidade e não historicidade. Produtividade na repetição, variedade sem ruptura. (ORLANDI, 2010: 9)

Quando Orlandi (idem) descreve como se massifica o acontecimento pelo alcance da memória técnica, pensamos na grande mídia, que atinge a maioria da população, como a mídia televisiva. Nesse caso, as imagens não só são selecionadas e muitas vezes editadas, como há uma voz que se sobrepõe às mesmas num trabalho nítido de condução dos sentidos daquilo que está sendo mostrado ( $C f$. SOUZA, 2001). As imagens que estamos analisando não tiveram circulação na grande mídia, exatamente para se poder transmitir uma imagem estereotipada do índio, como o eterno selvagem, baderneiro. A falta de circulação ampla das imagens em foco ilustra bem a produtividade e eficácia da memória metálica na produção do acontecimento: só alguns sentidos são propagados, outros interditados.

Ainda na foto 2 acima, vale observar o contraste dos corpos no embate entre o Estado e o índio: blindados como os dos policiais e pintados como os do índio. Orlandi (2017) sobre o corpo do imigrante, observa que os corpos se identificam, se significam a partir de toda uma narratividade que os faz significar. A autora define narratividade, não como gênero, mas como processo, uma maneira pela qual uma memória se diz em 
processos identitários. Uma relação do sujeito com a memória, evidenciando como a memória se conta no sujeito. Os corpos pintados trazem à tona uma memória constitutiva do índio imaginário: um ser de ficção ao qual se junta um sem número de valores ideológicos de todo gênero: o primitivo, o herói idealizado, o exótico, o ser ecológico, o político. O que precisa ser domesticado, disciplinado, como se vê nessas fotos. E aí destacam-se dois processos: há o Estado que individua (como propõe Orlandi, idem) com critérios oficiais do que é ser índio: falar uma língua de índio, fazer festa de índio, usar pinturas e adereços de índio. E há também um movimento de individualização do próprio índio em torno de um corpo que já se transfigurou em suas práticas no cotidiano e na vivência de um mundo outro. Entretanto, se o Estado assim o significa, é com pinturas e adereços tribais que ele parte para o confronto em busca de seus direitos.

Há ainda duas fotos que queremos analisar, tomadas como paráfrases visuais do mito Bakairi.

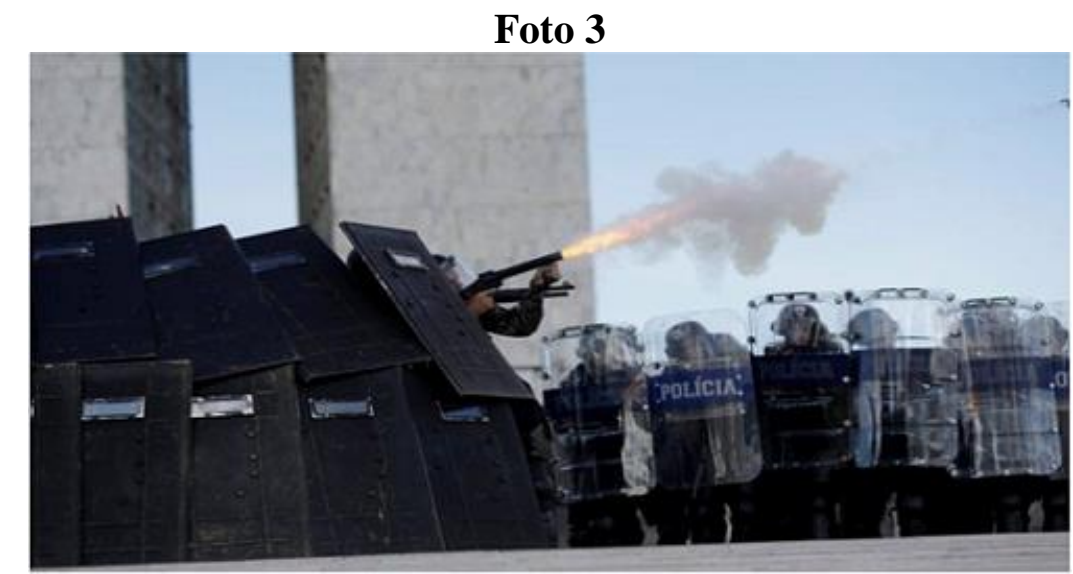

Fonte: http://www.bbc.com/news/world-latin-america-39717329

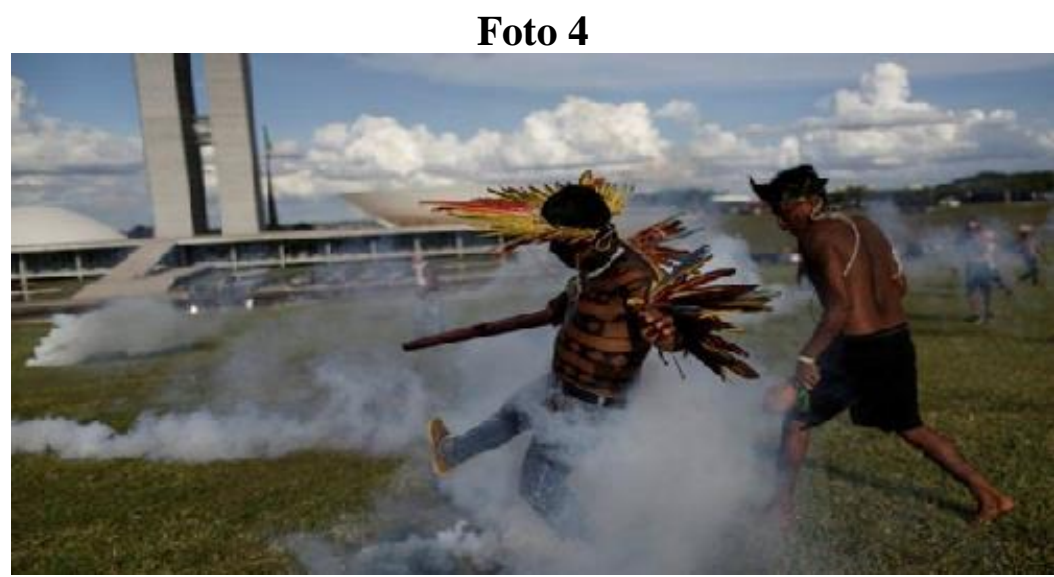

Fonte: http://www.bbc.com/news/world-latin-america-39717329 
As fotos (3) e (4) retratam o momento em que os indígenas estão sendo atacados, provavelmente, com bombas de gás com a função de causar a dispersão do grupo. Em meus trabalhos tenho definido o mito, em termos discursivos, como fundador. A discursividade do mito pode ser lida como fundadora em dois sentidos: primeiro porque retoma a forma primeira, ontológica dos seres, trabalhando aí a identidade indígena e, segundo, porque ressignifica os fatos, instaurando uma outra memória, a que diz o confronto. A retomada do mito instaura, assim, uma outra forma de discursividade: ao mesmo tempo que fala do mundo num tempo mítico, institui o novo, incluindo nesse mundo o diferente. Essas retomadas são, porém, tanto coletivas como atemporais. O que nos leva a pensar o mito associado a uma autoria imemorial. São peças da memória constitutiva do grupo. No entanto, são peças que (re)contam a história do grupo num movimento de gestos de leitura ao mesmo tempo polissêmicos e fundadores. Polissêmicos porque o mito é sempre re-interpretado e atualizado ou pelo povo, ou pelos seus diferentes enunciadores.

Na versão de A onça e o tamanduá, registrada por Von den Steinen, o último evento que fecha o mito narra a oferta de um presente misterioso do tamanduá para a onça. Nesta versão, o tamanduá-bandeira se disfarça se apresentando como seu primo: entra em cena uma outra espécie de tamanduá, o tamanduá-mirim:

Ora essa, você não é mais um gigante!, - diziam todos.

Leve um veneno mágico! -diziam.

Assim, como as pessoas lhe sugeriram, o pequeno tamanduá levou o veneno

Mágico e botou na porta da casa do Oka [nome mítico da onça]. A Oka saiu e quando olhou: Deixaram algo especial para mim! - disse a onça. Ela abriu e Oka ficou doente. A onça morreu.

$(\text { Von den Steinen, 1892: 254) })^{12}$

Na versão do estudioso alemão, há três encontros entre a onça e o tamanduá, saindo sempre o tamanduá em vantagem. O desfecho do mito é o trecho acima, em que a onça morre. Na versão que gravamos e em nenhuma das versões atuais, a onça, no caso o índio, morre. Os três encontros acontecem, mas o mito hoje em dia acaba sem um desfecho. A morte da onça fica silenciada. Assinalamos que em termos políticoideológicos, muitos mitos acabam por concretizar metaforicamente a história do confronto, quando os mitos se reatualizam numa forma clara de denúncia e resistência. No movimento desses gestos de sentido, pode-se ainda perceber a história da forma-

\footnotetext{
12 Tradução do original de nossa autoria.
} 
sujeito-índio, pensada por nós não como a forma-sujeito do capitalismo, mas, ainda assim com base em Pêcheux (1975: 163), quando afirma que "a interpelação do indivíduo em sujeito de seu discurso se efetua pela identificação (do sujeito) com a formação discursiva que o domina (isto é na qual ele é constituído como sujeito)". Uma nítida diferença - aquela que aponta a res-significação do mito a partir da presença do outro - assinala duas formas-sujeito. Uma que, talvez, num momento mais crítico do contato constrói o mito num tom que denuncia a morte do índio. E outra, que re-diz o mesmo mito, mas que aponta, cem anos mais tarde, uma linha de fuga: a resistência do índio instaurada na materialidade do seu discurso, traduzido por um jogo tenso de interpretações.

Observações desse tipo sobre a narrativa de vários mitos e outras relatos históricos é que fazem reafirmar mais uma vez a definição do mito como um discurso fundador. O que se tem nesse processo é um exemplo claro de ruptura, quando se instala uma outra memória para os Bakairi sobre o confronto índio X não-índio. Nesse sentido, o mito abre espaço a discursos outros, fundadores, não apenas por estarem na origem, mas porque o índio se instala como autor da enunciação do mito, articulando outros sentidos e atualizando o sentido do mito no curso da história. (Cf. SOUZA, 2008)

Vale a pena aqui um parêntese para precisar melhor a noção de memória pressuposta em nossa reflexão. Para que um acontecimento ou um saber seja lembrado não basta colocar em jogo uma memória social. Existe a necessidade de que o acontecimento lembrado reencontre sua atualização; e, sobretudo, é preciso que ele seja reconstruído a partir de dados e noções comuns aos diferentes membros da comunidade social. Esse traço em comum, essa dimensão entre sujeitos e em grupo especifica, como afirma Halbwachs (1950: p. 70), a memória coletiva. Mas a contrapartida seria que a memória coletiva "só retém do passado o que ainda é vivo ou capaz de viver na consciência do grupo que o mantém. Por definição, ela não ultrapassa o limite do grupo ${ }^{13}$." Daí podermos falar, a partir desse aspecto, do mito como fundador da identidade Bakairi e, por extensão, da identidade indígena. (SOUZA, idem). E poder observar pelas fotos trazidas que o confronto enquanto acontecimento instaura a memória coletiva,

Voltando às fotos, que paráfrases estão aí historicamente significando? As bombas atiradas do alto de carros de guerra surpreendem como mágica, como o antigo

\footnotetext{
${ }^{13}$ A noção de grupo se define pelo conjunto de indivíduos pertencentes a uma comunidade capaz de manter vivo um "pensamento contínuo" preservado na e pela memória coletiva. (Halbwachs, idem)
} 
presente do tamanduá (foto 3), mas hoje em dia os indígenas devolvem "os presentes" ao inimigo (foto 4), com as armas de que dispõem: o corpo miticamente marcado como primitivo e selvagem. Falar em paráfrases visuais é diferente de buscar indícios, pistas. A rede de paráfrases traz à tona sítios de significância - revelando uma arquitetura visual - que, por efeito metafórico, nos permite "visualizar" a disputa entre dois mundos.

\section{Conclusão}

Que relação há entre as fotos aqui mostradas e o mito bakairi? Partimos desta questão para entender o papel das paráfrases visuais na composição da arquitetura discursivo-visual: chegamos ao domínio do tempo que atualiza o acontecimento, no caso, o confronto histórico entre dois mundos, materializado em paráfrases visuais. "Pensar a imagem como dispositivo de constituição do político é procurar entender toda sua eficácia simbólica e colocar à mostra o seu papel de intervenção na construção da memória.” (SOUZA, 2006 e 2017).

Uma nota sobre o funcionamento do discurso indígena, nos faz retomar considerações nossas a esse respeito (SOUZA, 1994). Propor no discurso indígena a noção de sujeito-de-direito é problemático, dada a dificuldade de se definir no âmbito da conjuntura nacional, o estatuto da(s) sociedade(s) indígena(s) com suas próprias leis, direitos e deveres. O modo como a forma-sujeito-índio é interpelada-constituída pela ideologia, obviamente, é diferente do modo como o operário, o patrão, o soldado, são interpelados. Não se coloca transferir para a sociedade indígena o mesmo painel desenhado pela luta de classes, sustentada pela questão econômica. É possível, porém, falar de uma outra luta, uma luta de etnias, onde o poder se expressa através da dominação, da catequese, visando a disciplinarização do índio. Mas o índio não se intimida, procura linhas de fuga, como é o caso do esquecimento da morte do índio no mito que exploramos hoje em dia. Esta e outras formas de esquecimento materializam no discurso indígena movimentos de resistência, e aqui tão claros - ao nosso olhar! - na discursividade não verbal inscrita na forma como o corpo-índio se significa.

Uma outra questão que atravessa todo o tempo este texto - existe um real do visível?. Provavelmente não, mas existe um real da história que não está na saída nem na chegada, mas no meio da travessia, quando se toma de empréstimo as palavras de Guimarães Rosa. 


\section{Referências bibliográficas}

ACHARD, P. Memória e produção discursiva do sentido. Papel da Memória. Campinas, SP: Pontes Editores, 1999

BARTHES, R. 1980: A câmara clara. Petrópolis, RJ: Editora Nova Fronteira, 1984

BARTHES, R. O óbvio e o obtuso. Petrópolis, RJ: Editora Nova Fronteira, 1990

COURTINE, J-J. Decifrar o corpo - Pensar com Foucault. Petrópolis, RJ: Editora Vozes, 2013

FOUCAULT, M. A arqueologia do saber. Rio de Janeiro: Forense Universitária. 1987

ORLANDI, E. As Formas do Silêncio. Campinas: UNICAMP Editora, 1992

ORLANDI, E. Efeitos do verbal sobre o não-verbal. Rua, Campinas: 1 UNICAMP Editora, 1995

ORLANDI, E. Análise de discurso. Princípios e procedimentos. Campinas, SP: Pontes Editores, 1999

ORLANDI, E. A contrapelo: incursão teórica na tecnologia - discurso eletrônico, escola, cidade. Rua v. 16, n.2, 2010

ORLANDI, E Eu, tu, ele. Discurso e real da história. Campinas, SP: Pontes Editores, 2017.

PÊCHEUX, M. Les Verités de la Palice, Paris: Maspero, 1975

PÊCHEUX, M. Papel da Memória. Campinas, SP: Pontes Editores, 1999

PÊCHEUX, M. Análise sintática e paráfrase discuriva. In: Orlandi, E. (org.) Análise de Discurso - Michel Pêcheux. Campinas, SP: Pontes Editores, 2011

SOUZA, Tania C.C. de. Discurso e oralidade. Um estudo em língua indígena. Tese de Doutorado. Instituto de Estudos da Linguagem, UNICAMP, 1994

SOUZA, Tania C.C. Imagem e Sentido, texto-apostila utilizado no curso ANÁLISE DO DISCURSO do Instituto de Artes de Comunicação Social, Niterói, primeiro semestre de 1996.

SOUZA, Tania C.C. Discurso e imagem: perspectivas de análise do não-verbal, Conferência no $2^{\circ}$ Colóquio de Analistas del Discurso, Universidad del Plata, Instituto de Linguística da Universidad de Buenos Aires, La Plata e Buenos Aires, 1997

SOUZA, Tania C.C. Discurso e imagem: perspectivas de análise do não-verbal. CIBERLEGENDA, Niteroi, RJ: v.1, p.15 - 32, 1998.

SOUZA, Tania C.C. Carnaval e memória: das imagens e dos discursos, Contracampo, Niterói, RJ: 5, UFF, 2000

SOUZA, Tania C.C. A análise do não verbal e os usos da imagem nos meios de comunicação, Rua, Campinas: 7, Unicamp, 2001

SOUZA, Tania C.C. Discurso e imagem: uma questão política. IN: Lenzi, L.H.C.; Da Ros, S.Z.; Souza, A.M. Alves de.; Gonçalves, M.M.. (Org.). Imagem: intervenção e pesquisa. Florianópolis, SC: NUP, 2006, p. 079-101. 1a. ed. 
SOUZA, Tania C.C. Mito e discursividade: um processo metonímico. Revista Boitatá, v.6, p.23 - 35, 2008.

SOUZA, Tania C.C. Imagem, textualidade e materialidade discursiva. In: Análise de Discurso no Brasil: pensando o impensado sempre. Uma homenagem a Eni Orlandi.1 ed. Campinas, SP: Editora RG, 2011, p. 387-400.

SOUZA, Tania C.C. Gestos de interpretação e olhar(es) nas fotos de Curt Nimuendajú: índios no Brasil. Comunicação VII Jornadas de Estudos de Linguagem - JEL, UERJ: 2012.

SOUZA, Tania C.C. Gestos de interpretação e olhar(es) nas fotos de Curt Nimuendajú: índios no Brasil. Revista FSA, v.10, p.287 - 301, 2013.

SOUZA, Tania C.C. Discurso e cinema: (i)materialidades discursivas e efeitos metafóricos. CASA (Araraquara), v.11, p.23 - 37, 2013a.

SOUZA, Tania C.C. Três perspectivas na análise da imagem. Palestra. Programa de Pós-graduação Stricto Sensu em Letras, Cascavel, PR: Unioeste, 2016

SOUZA, Tania C.C. Imagem como dispositivo de intervenção na memória. Conferência. I Encontro Nacional em Análise de Discurso. Porto Velho, RO: UNIR,

Von den Steinen, K. Die Bakaïrí Sprache. Leipizig, 1982

Data de Recebimento: 27/02/2018

Data de Aprovação: 26/03/2018 


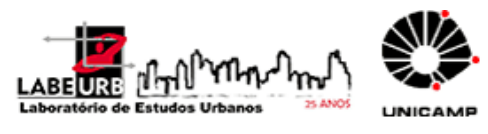

\section{Para citar essa obra:}

SOUZA, Tania Conceição Clemente de. Perspectivas da análise do (in)visível: a arquitetura discursiva do não verbal In: RUA [online]. $n^{\circ}$. 24. Volume 1 - p. 17-35 - e-ISSN 2179-9911 junho/2018. Consultada no Portal Labeurb - Revista do Laboratório de Estudos Urbanos do Núcleo de Desenvolvimento da Criatividade.

http://www.labeurb.unicamp.br/rua/

Capa: AFP. Disponível em: http://www.bbc.com/news/world-latin-america-39717329

Laboratório de Estudos Urbanos - LABEURB

Núcleo de Desenvolvimento da Criatividade - NUDECRI

Universidade Estadual de Campinas - UNICAMP

http://www.labeurb.unicamp.br/

Endereço:

LABEURB - LABORATÓRIO DE ESTUDOS URBANOS

UNICAMP/COCEN / NUDECRI

CAIXA POSTAL 6166

Campinas/SP - Brasil

CEP 13083-892

Fone/ Fax: (19) 3521-7900

Contato: http://www.labeurb.unicamp.br/contato 